Macedo, P., Santos, F. D., Tristan Pedersen, J., \& Penha-Lopes, G. (2021). Climate action: Is coronavirus what we have been waiting for? (and now what?). Local Environment, 1-7. https://doi.org/10.1080/13549839.2021.1916902

This is an Accepted Manuscript of an article published by Taylor \& Francis in Local Environment on 28 Apr 2021, available online: https://www.tandfonline.com/doi/full/10.1080/13549839.2021.1916902 


\title{
Climate action: is coronavirus what we have been waiting for? (and now what?)
}

\author{
Pedro Macedo ${ }^{\text {a*, Filipe Duarte Santos }}{ }^{\mathrm{a}}$, Jiesper Tristan Pedersen ${ }^{\mathrm{a}}$ and Gil \\ Penha-Lopes ${ }^{\mathrm{a}}$
}

${ }^{a}$ Centre for Ecology, Evolution and Environmental Changes, Faculdade de Ciências, Universidade de Lisboa, 1749-016 Lisbon, Portugal

*pamacedo@fc.ul.pt

Pedro Macedo wishes to acknowledge the 'Fundação para a Ciência e a Tecnologia', the Portuguese public agency that supports science, technology and innovation (scholarship $\mathrm{PD} / \mathrm{BD} / 128170 / 2016)$.

In the beginning of 2020, it looked like serious climate action was finally going to take place after decades of procrastination, but we are now inevitably leaving the transformation path. Abruptly (and remarkably), the coronavirus outbreak silenced ongoing efforts to protect climate, while also partly bringing carbon emissions to a halt. A global tragedy is still unfolding with vast social impacts and we are reaching a roundabout with several distinct exits. While embracing the uncertainty of current times, we try to envision likely transition pathways using the multi-level perspective. Climate activists, social innovators, dreamers, and networkers are expected to gain momentum and play critical roles in a sequence of co-evolutionary waves leading to a just, conscious, and regenerative recovery.

Keywords: climate action; COVID-19; transformation; transition pathways; multi-level perspective; community resilience 


\section{Introduction}

2020 was expected to be the beginning of a decade of climate action, finally facing "the most systemic threat to humankind" (Guterres 2018), set to anticipate the future (Anderson 2010). Detailed scientific knowledge, civil society uprising, bold political decisions, technological breakthroughs, extensive media coverage... everything looked ready to nurture the seeds of a good Anthropocene (Bennett et al. 2016). For some, it looked like we were (finally) at the edge of a quantum leap (O’Brien 2016) or social tipping point (Otto et al. 2020; Hopkins 2019a).

But, when the 2020 spring was arriving, another entirely different thing was spreading globally: we were in the middle of a new coronavirus pandemic, that abruptly disrupted our lives and 'silenced' climate action (Temple 2020; Bordoff 2020). The outbreak of 2019 novel coronavirus diseases (COVID-19) in China (Wu and McGoogan 2020) should be no surprise (Fan et al. 2019; Balkhair, Al Maamari, and Ba Alawi 2013; Zlojutro, Rey, and Gardner 2019). The new pandemic is part of the observed rise of animal-borne infectious diseases (Smith et al. 2014), which is likely a consequence of our broken relation with nature (Brulliard 2020). However, the rapidly and profound impact in many areas of our society was quite a shock, including climate action. Suddenly, climate protests were cancelled and even become unimaginable in the usual format. Climate change almost disappeared from the political and media agendas.

Somehow ironically, the new virus withdrew climate action while simultaneously caused vast and unprecedented climate mitigation. Carbon emitters that looked untouchable, like air travel, almost came to a full stop in just a few weeks. The oil and gas sector were thrown into turmoil (Carrington, Ambrose, and Taylor 2020). Social isolation and a decrease in industrial activity lowered pollution levels and 
allowed nature to recover in many places (Henriques 2020). Beyond any wild activist's dreams.

The crisis is also bringing new insights into our capacity to adapt. Vast volunteers' initiatives from neighbourhoods, media, or companies are minimizing some of the impacts by offering innovative services (e.g. Tech4Covid19 2020; South et al. 2020). Emergency declarations allowed radical political decisions that did not face significant civil resistance. Even extreme precautionary laws and practice changes are accepted broadly and anticipating actions become legitimate (Dunford et al. 2020). Health practitioners and researchers mobilized, possibly on an unprecedented scale (Cueni 2020). At the international level, some degree of coordination allowed to face the worst consequences.

An obvious question is: why were we not already supporting transformation in a similar way to face the climate crisis? Possibly a reduction of global greenhouse gas emissions on the scale that has been witnessed since January 2020 could not be achieved on a consensual way because its suddenness would provoke harmful consequences for employment and well-being. However, the sudden decrease in emissions proved that when higher values, with immediate repercussions, such as human lives, it is possible do the 'right' thing, even if that harms our current economic system. The problem is that climate change is seen as a long-term threat that does not demand immediate responses (Comerford 2020). With the coronavirus we face an immediate risk. We face the consequences of the risk right here and right now.

Like all crises, this pandemic brings opportunities. And climate activists (and others) are already asking how we can make the reductions in greenhouse gas emissions permanent, favouring long-lasting shifts away from carbon-intensive behaviours. It is argued that "climate change should be seen with equal, and probably even greater, 
urgency because of its increasing, planet-wide, and in many ways permanent, foreseeable problematic impacts" (Heyd 2020).

\section{Moving away from transformation}

Sustainability transitions have already been extensively studied (Köhler et al. 2019). Climate change was creating disruptive change that was perceived as moderate. Accordingly, regime actors were slowly changing the direction of development trajectories, frustrating demands from several outsiders, including activists and researchers (Ripple et al. 2019). Using the multi-level perspective on transitions, we could name this pre-COVID path as transformation (Geels and Schot 2007).

The COVID-19 outbreak can be considered a specific shock, as defined by Suarez and Oliva (2005), with high amplitude and speed - its intensity derails this gradual transformative path, as discussed in the introduction. The now evident disruptive change may cause a sequence of transition pathways, leading to reconfiguration, and followed by de-alignment and re-alignment, as described by Geels and Schot (2007). This possible sequence of pathways will now be discussed.

The new coronavirus is challenging regimes profoundly and can bring the destabilization that was considered necessary to overcome path-dependencies and lockins. The creative destruction (Geels 2014) that we have been 'waiting for', as mentioned in the intended provocative title of this paper. The crisis is also expected to create a paradigm shift that can act as a deep leverage point, altering the systems' intent, as described by Abson et al. (2017). A strong sense of interconnectedness and the magnification of altruism and localism might be emerging (Foster 2020; Boni 2020).

With the exacerbation of problems, regime actors might become more willing to incorporate symbiotic niche-innovations, particularly the ones that focus on community resilience (Penha-Lopes and Henfrey 2019). This openness to a reconfiguration path, as 
described by Geels and Schot (2007), is expected to grow when resources of national governments and allied business actors get depleted, making local, rooted responses critical.

Possibly, this reconfiguration will not be enough to deal with the current health crisis, mainly due to the expected economic impact, and incumbent actors might begin to lose faith and legitimacy, unable to incorporate the lessons of the crisis to build more sustainable futures. Prolonged uncertainty and the collapse of several systems might happen ('de-alignment'), (already) leading to vigorous discussions on possible futures (Mair 2020). If one (or more) niche-innovation becomes dominant, it can form the core for re-alignment of a new regime (Geels and Schot 2007).

\section{Taking advantage of windows of opportunity}

For community resilience (including climate action) to replace the current system and become the 'new normal', several propositions would need to be met (Fazey et al. 2018). These include dealing with inequalities (that are increasing even faster due to the coronavirus crisis) and focus on the unprivileged, alongside with the formulation of updated change narratives (Wittmayer et al. 2019). This can bring hope and unleash imagination (Hopkins 2019b). We envision three waves for supporting regime substitution in a medium to long term perspective, fully taking advantage of the windows of opportunity created by the coronavirus.

The first wave is about 'resistance'. Changemakers are expected to protect themselves from the immediate threats by avoiding or delaying contamination, assuring means of subsisting, and dealing with the psychological impacts of quarantine (Flu Mob 2020a). Whenever possible, virtual mobilization can happen to prevent probable tendencies to 'business-as-usual' approaches to the crisis that might lead to an emissions rebound (Peters 2020). This would include strong resistance to any kind of 
‘stimulus packages’ to carbon-intense activities (Green Stimulus Proposal 2020).

Several initiatives already advocated for a just recovery (e.g. 350 2020).

Even with clear limitations, climate movements can explore the new possibilities (Rose 2020) and make good use of people's quarantines by way of tools like digital rallies and on-line broadcasting (Sunrise Movement 2020; Climáximo 2020). "Refusing to go back to work" is already under discussion (White 2020), and we are challenged to ask the 'right' questions (Flu Mob 2020b), such as "what world shall we live in?" (Eisenstein 2020).

The second wave, which we name 'support', can explore the possibilities of the aforementioned reconfiguration path, further backing the change of the "rules of the game" (Avelino et al. 2017). As the pandemic spreads and formal systems get overwhelmed, transformative social innovators are promoting local responses. The ecovillages and permaculture projects worldwide have more than 50 years of experience of living of the land and building local communities (Penha-Lopes and Henfrey 2019). The Transition movement is well-positioned in the urban areas to play a constructive role in the process due to a relatively effective experience in reflecting and acting locally in the perspective of global collapse (Feola and Nunes 2014; Loorbach et al. 2016). Its capacity to move across a wide political spectrum, an optimistic approach, and a focus on resilience and collaboration (McGregor and Crowther 2016; Macedo et al. 2020) might favour the symbioses with (still) prevailing regime actors.

Grassroots initiatives can contribute effectively to fight the virus if they manage to adapt to the changing context (Engler 2020), gaining momentum in the process. From 'street activism' we might start getting caretakers, working as fungi to nurture the needed parts of the system and building an interconnected and trustworthy community, 
with the seeds of new possibilities. From caretakers on a healthier current system, many might start becoming midwives of a new society.

The third wave, related to 're-alignment', might arise following a broader collapse, including a breakdown of democracy as we know it. A new translocal governance might emerge by linking cross-scalar, collective, and distributive agencies (Moragues-Faus and Sonnino 2019).

To effectively countervail the current power structures, there is a call (Avelino 2019) for more strategic collaboration between movements and networks (alongside the spread of new narratives). Entities like ECOLISE, the European Network for Community-led Initiatives on Climate Change and Sustainability, might play a critical role by joining grassroots initiatives and active local governments (EUROCITIES 2020). These bridging organizations also connect local actors and communities with other scales of organizations, bring resources, and mobilize knowledge and social memory (Folke et al. 2005). Equally, action researchers are expected to support the coevolutionary processes by facilitating governance, social learning, resourcing, and reflexive monitoring (Avelino et al. 2019).

\section{A new regenerative paradigm}

Without pressure from incumbent actors and facilitated social acceptance due to the mentioned paradigm shift, a large-scale transition pathway might take place (Hof et al. 2016). More important that jumping to preconceived solutions considered best practices or more sustainable ('what'), we are called to move upstream. Daniel Wahl (Wahl 2016) invites us to question not only 'what' we manifest, 'how' we implement it but also 'why' we are being it and doing it. Using a framework like the 'iceberg model', an individual or group can discover the patterns of behaviour, supporting structures, and mental models (such as values, beliefs and assumptions) that underlie a particular event 
or action.

Also, Daniel integrates in his book frameworks that allow us to be designers of a regenerative culture. Terry Irwin wrote "Until designers shift to a more holistic worldview, design will continue to be part of the problem, not the solution" (2012). For that reason, integral theory frameworks (O’Brien and Hochachka 2005), such as AQAL (all quadrants, all levels) allow us to operate in the world considering inner and exterior dimensions as well as individual and collective, but also the consciousness levels in our different lines of development (such as cognitive, emotional, spiritual and others).

The three horizons framework (Sharpe et al. 2016) also bring clarity to all involved in planning, once it considers that we always have to address and nurture the potential and needs of: the present system and situation ( $\left(1^{\text {st }}\right.$ horizon $)$, the end-state reality we want live in the future ( $3^{\text {rd }}$ horizon) and the transition state in between both, where some parts of the current system need to adapt, be reinvented or die, and others need to be created, prototyped and developed ( $2^{\text {nd }}$ horizon).

Since 1970 we are living beyond Earth regenerative capacity (Global Footprint Network 2020). Regenesis and their members have been testing regenerative development frameworks all over the world (Mang and Haggard 2016). The work is focused on the developmental potential of place (including territory and its community) with the understanding that we design living nested systems. By exploring the history and uniqueness of the place with the local community and stakeholders in that region, they invoke a deep sense of belonging and ownership.

Inviting all to see the potential of that region (idem), something we all have in common regardless of our other differences, participants understand or can take up new roles of value adding that benefits both community and territory (taking into consideration the human, social, natural, produced and financial capitals). This tends to 
enhance their will to express themselves in the three lines of work: developing themselves ( $1^{\text {st }}$ line of work), developing the capability of the group, team or initiative they are involved ( $2^{\text {nd }}$ line of work) and serving the development and evolution of larger nested wholes (or the systems beyond the scale it's been co-creatively designing, $3^{\text {rd }}$ line of work).

Accomplished regenerative practitioners might trigger an evolutionary process in the communities they serve that does not stop when the project or policy/funding scheme is over. They are expected to leave the communities better equipped, with new energy (vitality), agency (viability) and capabilities, to keep moving forward (evolution), despite difficulties and obstructions and with a stronger connection to their place, both the natural and human build environment and 'neighbours'.

\section{Conclusion}

In this paper, we have tried to mix both informed and wishful guesses to possible outcomes of the COVID-19 crisis, namely relating sustainability transitions. Before closing, we stress two aspects. First, the COVID-19 is primarily "an international crisis, and a personal tragedy for those who have lost, and will lose, loved ones" (Peters 2020). The burden is expected to "fall disproportionately on the old, the weak and the poor" (Foster 2020). If some were fighting to close airports (Periskop 2020), no one for sure wanted them to become morgues (BBC 2020). Exploring windows of opportunities does not mean to welcome the epidemic.

The second call for attention relates to the uncertainty of the scenarios explored. Path dependencies are intense, and previous crises frustrated similar expectations (Loorbach et al. 2016; Eisenstein 2020). Many other situations, like the emergence of authoritarianism and the perpetuation of a culture of domination, are for sure possible or even probable (Mair 2020; Eisenstein 2020). Also, a reinforced transformation path 
might emerge after the crisis, due to a new political culture of prevention and long-term thinking. We need to acknowledge our ignorance and expect the unimaginable. We have to "accept that Earth is winning", avoid the "saviour narrative" and "accept the limitation of what we can do now" (White 2020).

For a deep transformation towards a better collective future to happen, not only climate activists, social innovators, action researchers, and networkers, but all society, including regime actors, are called to explore the new possibilities and collectively create a new culture of caring and regeneration. We might not get a unique opportunity like this one to redeem our generation.

\section{References}

350. 2020. "Open Letter: Principles for a \#JustRecovery from COVID-19." https://350.org/just-recovery/.

Abson, David J., Joern Fischer, Julia Leventon, Jens Newig, Thomas Schomerus, Ulli Vilsmaier, Henrik von Wehrden, et al. 2017. "Leverage Points for Sustainability Transformation.” Ambio 46 (1). Springer Netherlands: 30-39. doi:10.1007/s13280016-0800-y.

Anderson, Ben. 2010. "Preemption, Precaution, Preparedness: Anticipatory Action and Future Geographies." Progress in Human Geography 34 (6): 777-798. doi:10.1177/0309132510362600.

Avelino, Flor. 2019. "Time to Ignite the Power of Translocal Social Movements." The Broker. http://www.thebrokeronline.eu/Blogs/Inclusive-Economy-Europe/Time-toignite-the-power-of-translocal-social-movements.

Avelino, Flor, Julia M. Wittmayer, René Kemp, and Alex Haxeltine. 2017. “GameChangers and Transformative Social Innovation.” Ecology and Society 22 (4): art41. doi:10.5751/ES-09897-220441.

Avelino, Flor, Julia M Wittmayer, Bonno Pel, Paul Weaver, Adina Dumitru, Alex Haxeltine, René Kemp, et al. 2019. “Transformative Social Innovation and (Dis)Empowerment." Technological Forecasting and Social Change 145 (May 
2015). Elsevier: 195-206. doi:10.1016/j.techfore.2017.05.002.

Balkhair, Abdullah, Khuloud Al Maamari, and Fatma Ba Alawi. 2013. "The Struggle Against MERS-CoV (The Novel Coronavirus)." Oman Medical Journal 28 (4): 226-227. doi:10.5001/omj.2013.66.

BBC. 2020. "Coronavirus: Birmingham Airport Mortuary Work under Way.” BBC News. https://www.bbc.com/news/uk-england-birmingham-52067885.

Bennett, Elena M., Martin Solan, Reinette Biggs, Timon McPhearson, Albert V. Norström, Per Olsson, Laura Pereira, et al. 2016. "Bright Spots: Seeds of a Good Anthropocene." Frontiers in Ecology and the Environment 14 (8): 441-448. doi:10.1002/fee.1309.

Boni, Anna Lisa. 2020. "Love in the Time of Cho...rona." Eurocities. http://www.eurocities.eu/eurocities/news/Love-in-the-time-of-cho-rona-WSPOBMULJ8.

Bordoff, Jason. 2020. “Coronavirus Pandemic Shows Exactly Why There Won't Be Global Action on Climate Change." FP. https://foreignpolicy.com/2020/03/27/coronavirus-pandemic-shows-why-noglobal-progress-on-climate-change/.

Brulliard, Karin. 2020. “Covid-19: A Próxima Pandemia Vai Chegar Se Não Mudarmos a Forma Como Interagimos Com a Vida Selvagem." PÚBLICO. https://www.publico.pt/2020/04/07/p3/noticia/covid19-proxima-pandemia-vaichegar-nao-mudarmos-forma-interagimos-vida-selvagem-1911340.

Carrington, Damian, Jillian Ambrose, and Matthew Taylor. 2020. "Will the Coronavirus Kill the Oil Industry and Help Save the Climate?" The Guardian. https://www.theguardian.com/environment/2020/apr/01/the-fossil-fuel-industry-isbroken-will-a-cleaner-climate-be-the-result.

Climáximo. 2020. “Climáximo Lança Programa Crítico ‘Quarentena Climática.”” http://www.climaximo.pt/2020/03/13/climaximo-lanca-programa-criticoquarentena-climatica/.

Comerford, David. 2020. "Coronavirus Should Give Us Hope That We Are Able to Tackle the Climate Crisis." The Conversation. https://theconversation.com/coronavirus-should-give-us-hope-that-we-are-able-to- 
tackle-the-climate-crisis-133174.

Cueni, Thomas B. 2020. "COVID-19: An Unprecedented Mobilization of the Scientific Community.” IFPMA. https://www.ifpma.org/global-health-matters/covid-19-anunprecedented-mobilization-of-the-scientific-community/.

Dunford, Daniel, Becky Dale, Nassos Stylianou, Ed Lowther, Maryam Ahmed, and Irene de la Torre Arenas. 2020. "Coronavirus: The World in Lockdown in Maps and Charts.” BBC News. https://www.bbc.com/news/world-52103747.

Eisenstein, Charles. 2020. "The Coronation.” https://charleseisenstein.org/essays/thecoronation/?_page=5.

Engler, Paul. 2020. “Coronavirus Is a Historic Trigger Event — and It Needs a Movement to Respond." Waging Nonviolence. https://wagingnonviolence.org/2020/03/coronavirus-historic-trigger-event-needsmovement-response/.

EUROCITIES. 2020. "Live Updates COVID-19: European Cities Respond to the Coronavirus Crisis.” https://covidnews.eurocities.eu/.

Fan, Yi, Kai Zhao, Zheng-Li Shi, and Peng Zhou. 2019. "Bat Coronaviruses in China." Viruses 11 (3): 210. doi:10.3390/v11030210.

Fazey, I, E Carmen, FS Chapin, H Ross, J Rao-Williams, C Lyon, ILC Connon, BA Searle, and K Knox. 2018. "Community Resilience for a $1.5^{\circ} \mathrm{C}$ World." Current Opinion in Environmental Sustainability 31 (April). Elsevier B.V.: 30-40. doi:10.1016/j.cosust.2017.12.006.

Feola, Giuseppe, and Richard Nunes. 2014. "Success and Failure of Grassroots Innovations for Addressing Climate Change: The Case of the Transition Movement." Global Environmental Change 24 (1). Elsevier Ltd: 232-250. doi:10.1016/j.gloenvcha.2013.11.011.

Flu Mob. 2020a. "Flu Mob - Be the Vaccine.” https://flumob.org/.

Flu Mob. 2020b. “The New Reality: What Question Should We Be Asking?” https://flumob.org/the-new-reality.

Folke, Carl, Thomas Hahn, Per Olsson, and Jon Norberg. 2005. "Adaptive Governance of Social-Ecological Systems." Annual Review of Environment and Resources 30 
(1): 441-473. doi:10.1146/annurev.energy.30.050504.144511.

Foster, Charles. 2020. "Coronavirus Pandemic Is a Disaster for the World, but a Few Good Things Might Emerge from It." The Conversation.

https://theconversation.com/coronavirus-pandemic-is-a-disaster-for-the-world-buta-few-good-things-might-emerge-from-it-133723.

Geels, Frank W. 2014. "Regime Resistance against Low-Carbon Transitions: Introducing Politics and Power into the Multi-Level Perspective.” Theory, Culture \& Society 31 (5): 21-40. doi:10.1177/0263276414531627.

Geels, Frank W., and Johan Schot. 2007. “Typology of Sociotechnical Transition Pathways.” Research Policy 36 (3): 399-417. doi:10.1016/j.respol.2007.01.003.

Global Footprint Network. 2020. "Earth Overshoot Day." https://www.overshootday.org/.

Green Stimulus Proposal. 2020. "A Green Stimulus to Rebuild Our Economy.” Medium.https://medium.com/@green_stimulus_now/a-green-stimulus-to-rebuildour-economy-1e7030a1d9ee.

Guterres, António. 2018. “Secretary-General's Press Encounter on Climate Change.” United Nations Secretary-General. https://www.un.org/sg/en/content/sg/pressencounter/2018-03-29/secretary-generals-press-encounter-climate-change-qa.

Henriques, Martha. 2020. "Will Covid-19 Have a Lasting Impact on the Environment? BBC Future." BBC Future. https://www.bbc.com/future/article/20200326-covid19-the-impact-of-coronavirus-on-the-environment.

Heyd, Thomas. 2020. "Covid-19 and Climate Change in the Times of the Anthropocene.” The Anthropocene Review, September, 205301962096179. doi:10.1177/2053019620961799.

Hof, Andries, Holger Berg, Niki Frantzeskaki, Anne Holsten, Detlef Van Vuuren, Steffen Maschmayer, Giorgia Silvestri, et al. 2016. Sustainability Transitions Towards Low-Carbon Societies. TESS, ARTS \& PATHWAYS.

Hopkins, Rob. 2019a. "What If Friday September 20th 2019 Was the Day the World Tipped?" https://www.robhopkins.net/2019/09/23/what-if-friday-september-20th2019-was-the-day-the-world-tipped/. 
Hopkins, Rob. 2019b. From What Is to What If: Unleashing the Power of Imagination to Create the Future We Want. London, UK: Chelsea Green Publishing.

Irwin, Terry. 2012. "Transforming the Design Process to Create Better Solutions." Solutions for a Sustainable and Desirable Future 3 (2): 1.

Köhler, Jonathan, Frank W. Geels, Florian Kern, Jochen Markard, Elsie Onsongo, Anna Wieczorek, Floortje Alkemade, et al. 2019. “An Agenda for Sustainability Transitions Research: State of the Art and Future Directions.” Environmental Innovation and Societal Transitions 31 (June): 1-32. doi:10.1016/j.eist.2019.01.004.

Loorbach, Derk, Flor Avelino, Alex Haxeltine, Julia M. Wittmayer, Tim O’Riordan, Paul Weaver, and René Kemp. 2016. "The Economic Crisis as a Game Changer? Exploring the Role of Social Construction in Sustainability Transitions.” Ecology and Society 21 (4): art15. doi:10.5751/ES-08761-210415.

Macedo, Pedro, Ana Huertas, Cristiano Bottone, Juan del Río, Nicola Hillary, Tommaso Brazzini, Julia M. Wittmayer, and Gil Penha-Lopes. 2020. "Learnings from Local Collaborative Transformations: Setting a Basis for a Sustainability Framework." Sustainability 12 (3): 795. doi:10.3390/su12030795.

Mair, Simon. 2020. "What Will the World Be like after Coronavirus? Four Possible Futures." The Conversation. https://theconversation.com/what-will-the-world-belike-after-coronavirus-four-possible-futures-134085.

Mang, Pamela., and Ben. Haggard. 2016. Regenerative Development. Hoboken, NJ, USA: John Wiley \& Sons, Inc. doi:10.1002/9781119149699.

McGregor, Callum, and Jim Crowther. 2016. "The Transition Movement as Politics and Pedagogy in Communities." Community Development Journal 53 (1): 8-24. doi:10.1093/cdj/bsw024.

Moragues-Faus, Ana, and Roberta Sonnino. 2019. "Re-Assembling Sustainable Food Cities: An Exploration of Translocal Governance and Its Multiple Agencies." Urban Studies 56 (4): 778-794. doi:10.1177/0042098018763038.

O’Brien, Karen, and Gail Hochachka. 2005. "Integral Adaptation to Climate Change." Journal of Integral Theory and Practice 5 (1): 89-102.

O’Brien, Karen L. 2016. “Climate Change and Social Transformations: Is It Time for a 
Quantum Leap?" Wiley Interdisciplinary Reviews: Climate Change 7 (5): 618626. doi:10.1002/wcc.413.

Otto, Ilona M., Jonathan F. Donges, Roger Cremades, Avit Bhowmik, Richard J. Hewitt, Wolfgang Lucht, Johan Rockström, et al. 2020. "Social Tipping Dynamics for Stabilizing Earth's Climate by 2050." Proceedings of the National Academy of Sciences 117 (5): 2354-2365. doi:10.1073/pnas.1900577117.

Penha-Lopes, Gil, and Tom Henfrey. 2019. Reshaping the Future: How Local Communities Are Catalysing Social, Economic and Ecological Transformation in Europe. The First Status Report on Community-Led Action on Sustainability and Climate Change in Europe. Brussels, Belgium: ECOLISE.

Periskop. 2020. "Stay Grounded.” https://stay-grounded.org/.

Peters, Glen. 2020. "How Changes Brought on by Coronavirus Could Help Tackle Climate Change." The Conversation. https://theconversation.com/how-changesbrought-on-by-coronavirus-could-help-tackle-climate-change-133509.

Ripple, William J, Christopher Wolf, Thomas M Newsome, Phoebe Barnard, and William R Moomaw. 2019. "World Scientists' Warning of a Climate Emergency." BioScience 70 (1): 100-100. doi:10.1093/biosci/biz088.

Rose, David. 2020. "Revealed: Extinction Rebellion's Plan to Exploit the Covid Crisis." The Spectator. https://www.spectator.co.uk/article/revealed-extinction-rebellion-splans-to-exploit-the-Covid-crisis.

Sharpe, Bill, Anthony Hodgson, Graham Leicester, Andrew Lyon, and Ioan Fazey. 2016. "Three Horizons: A Pathways Practice for Transformation.” Ecology and Society 21 (2): art47. doi:10.5751/ES-08388-210247.

Smith, Katherine F., Michael Goldberg, Samantha Rosenthal, Lynn Carlson, Jane Chen, Cici Chen, and Sohini Ramachandran. 2014. "Global Rise in Human Infectious Disease Outbreaks.” Journal of The Royal Society Interface 11 (101): 20140950. doi:10.1098/rsif.2014.0950.

South, J., J. Stansfield, R. Amlôt, and D. Weston. 2020. "Sustaining and Strengthening Community Resilience throughout the COVID-19 Pandemic and Beyond." Perspectives in Public Health 140 (6): 305-308. doi:10.1177/1757913920949582.

Suarez, Fernando F., and Rogelio Oliva. 2005. "Environmental Change and 
Organizational Transformation.” Industrial and Corporate Change 14 (6): 10171041. doi:10.1093/icc/dth078.

Sunrise Movement. 2020. "People's Bailout.” https://thepeoplesbailout.org/.

Tech4Covid19. 2020. "Tech4Covid19 · A Comunidade Tecnológica Portuguesa

Combate a Covid-19." https://tech4covid19.org/.

Temple, James. 2020. "Why the Coronavirus Outbreak Is Terrible News for Climate

Change." MIT Technology Review.

https://www.technologyreview.com/s/615338/coronavirus-emissions-climate-

change/.

Wahl, Daniel Christian. 2016. Designing Regenerative Cultures. Axminster, England: Triarchy Press.

White, Micah. 2020. "Micah White on Coronavirus, Climate Breakdown and What This Means for Protest." XRTV. https://www.youtube.com/watch?v=i-O7uDrapAk.

Wittmayer, J.M., J. Backhaus, F. Avelino, B. Pel, T. Strasser, I. Kunze, and L.

Zuijderwijk. 2019. "Narratives of Change: How Social Innovation Initiatives

Construct Societal Transformation.” Futures 112 (June). Elsevier Ltd: 102433. doi:10.1016/j.futures.2019.06.005.

Wu, Zunyou, and Jennifer M. McGoogan. 2020. "Characteristics of and Important Lessons From the Coronavirus Disease 2019 (COVID-19) Outbreak in China." JAMA 323 (13): 1239. doi:10.1001/jama.2020.2648.

Zlojutro, Aleksa, David Rey, and Lauren Gardner. 2019. “A Decision-Support Framework to Optimize Border Control for Global Outbreak Mitigation." Scientific Reports 9 (1). Springer US: 2216. doi:10.1038/s41598-019-38665-w. 